\title{
The New International Division of Cultural Labor
}

\section{La nueva división internacional del trabajo Cultural}

\author{
Toby Miller \\ Emeritus Distinguished Professor \\ (University of California, Riverside) \\ Revisited \\ - Guest paper - \\ Sir Walter Murdoch Professor of Cultural Policy Studies \\ (Murdoch University) \\ Profesor Invitado, Escuela de Comunicación Social \\ (Universidad del Norte) \\ Professor of Journalism, Media and Cultural Studies \\ (Cardiff University/Prifysgol Caerdydd) \\ Director of the Institute for Media and Creative Industries \\ (Loughborough University London)
}

Reception date: 10 July 2016

To cite this article: Miller, T. (2016): The New International Division of Cultural Labor Revisited, Icono 14, volumen 14 (2), pp. 97-121. doi: 10.7195/ ri14.v14i1.992 


\section{Abstract}

Radical political economy birthed the notion of the New International Division of Cultural Labor (NICL). It starts from the understanding that inequality colors everyday work and domestic life, stressing that although workers generate value, they rarely benefit commensurately, due to the power of capital. Whereas neoclassical or bourgeois economics assumes that supply and demand effectively determine the price of commodities, political economy examines the role of the state and capital in controlling labor and ideologizing consumers and citizens. In other words, orthodox economics concentrates on markets, regarding them as jewels of human behavior; the heterodox approach challenges this focus on consumption, stressing production as a source of value and a site of control. This paper analyse that the NICL has become a model for exploitation across territories, industries, and occupations, so thinking about it critically remains vital. Analytically, we need to focus on the division of labor as a theoretical, empirical, and organizational tool if we are to understand everyday work in a way that can enrich and liberate it in accord with ecological and employee experiences and necessities.

Key Words: Cultural Labor - NICL - Labor Market - Cultural production - Hollywood

\section{Resumen}

La economía política radical dió lugar al concepto de la Nueva División Internacional del Trabajo Cultural (NICL). Este parte de comprender las situaciones de desigualdad que se producen a diario tanto en el trabajo como en la vida doméstica. Aunque los trabajadores generan valor, rara vez se benefician proporcionalmente de este debido al poder del capital. Mientras que la economía neoclásica o burguesa asume que la oferta y demanda determinan el precio de los productos básicos, la economía política examina el papel del Estado y el capital en el control de mano de obra y la ideologización de consumidores y ciudadanos. En otras palabras, la economía ortodoxa se concentra en los mercados, considerándolos como las joyas de la conducta humana; el enfoque heterodoxo desafía este enfoque sobre el consumo, haciendo hincapié en la producción como una fuente de valor y un espacio de control. En este trabajo se analiza como el NICL se ha convertido en un modelo para la explotación en todos los territorios, las industrias y ocupaciones, por lo que ejercer un pensamiento crítico sigue siendo vital. Analíticamente, tenemos que centrarnos 
en la división del trabajo como una herramienta teórica, empírica, y de organización si queremos entender el trabajo diario de una manera que pueda enriquecerlo y liberarlo de acuerdo con las experiencias y las necesidades tanto de los trabajadores como ecológicas.

Palabras clave: Trabajo cultural - NICL - Mercado de trabajo - Producción cultural Hollywood

\section{Introduction}

Twenty-five years ago, I started publishing work that described a New International Division of Cultural Labor (NICL) (Miller, 1989; Miller, 1990). Since that time, the concept has generated further research (Miller, Lawrence, McKay \& Rowe, 2001; Miller \& Yúdice, 2002; Miller, Govil, McMurria, Maxwell, \& Wang, 2005; Maxwell \& Miller, 2012). In this essay, I reconsider the idea and find that it requires revision in order to describe the current conjuncture, in terms of both work and the environment.

Radical political economy birthed the notion of the NICL. It starts from the understanding that inequality colors everyday work and domestic life, stressing that although workers generate value, they rarely benefit commensurately, due to the power of capital. Political economy concentrates on those who are 'lost in the great anonymous sludge of history', in the words of the physicist-novelist CP Snow, where life 'has always been nasty, brutish and short."1 (Snow, 1987)

Whereas neoclassical or bourgeois economics assumes that supply and demand effectively (and supposedly rightly) determine the price of commodities, political economy examines the role of the state and capital in controlling labor and ideologizing consumers and citizens. In other words, orthodox economics concentrates on markets, regarding them as jewels of human behavior; the heterodox approach challenges this focus on consumption, stressing production as a source of value and a site of control.

This latter method argues that objects and services accrete value through corporate exploitation of the people who produce and provide them. The power of 
capital includes both authority over the conditions and possibilities of the workplace and surplus value, realized as profit. The division of labor links productivity, exploitation, and social control. As capital subdivides, multiplies, and spreads geographically, it hides the labor that constitutes it, focusing attention instead on technological wizardry, corporate stardom, or entrepreneurial fables (Marx, 1906).

Latin American political economists from this critical tradition generated a theory of dependent underdevelopment in the 1940s to explain why the industrial take-off experienced by Western Europe and the United States had not occurred elsewhere. They found that a global system saw value added and enjoyed in the Global North, where rich societies had become affluent through their colonial and international advantages. The global core imported ideas, fashions, resources, and people from the world's periphery and exported manufactures. 0ver the next three decades, this dependencia theory gained adherents across the Global South and among radicals everywhere. It was also linked to analyses of cultural imperialism (Prebisch, 1982; Cardoso, 2009).

\section{Labor Market Changes}

In the late 1970s, former colonial powers still dominated the Global South, exercising their power over client states to extract surplus value. But in some instances, domestic bourgeoisies were emerging. This was spectacularly true of Taiwan, South Korea, Hong Kong, and Singapore, known then as "Newly Industrialized Countries" or "Asian Tigers/Dragons." They benefited from US, Japanese, and West European control of transport and communications and investment, undertaken because they were capitalist states rather than Maoist or Marxist-Leninist ones in a region that Cold Warrior Yanquis feared might "turn Red." But they were not mere pawns of foreign governments and multinational corporations exploiting cheap labor and repatriating profit. Domestic wealth creation did occur, albeit in a way that constructed profound inequalities. Consider South Korea's rapid transformation from a very poor, essentially peasant, economy to a vibrant manufacturing one (Park, 1997). 
As the global value chain grew more diverse, those of us who were influenced by the dependistas and critics of cultural imperialism had to confront the fact that core-periphery relations were not uniform. This necessitated a partial break with dependencia as an explanatory mechanism. In its place-or perhaps supplementing it, given that such asymmetries continued to characterize much of the worldcame the idea of a New International Division of Labor (NIDL) (Fröbel, 1980).

Theorists of the NIDL acknowledged an increasingly global competition for working-class labor as manufacturers looked to invest in places where employees were capable, cheap, and compliant-the ultimate realization of a worldwide reserve army of workers. So the production of cars, boats, refrigerators, and televisions might still be funded from Tokyo or New York, but it was undertaken in Seoul or Guadalajara (Higgot \& Robinson, 1985).

An even more spectacular change in the market for labor occurred in the five years after 1989. The collapse of state socialism saw people from the former Soviet empire enter the capitalist world tout court. Then the People's Republic of China and India opened up to international competition. Virtually overnight, the global pool of workers doubled, as massive reserve armies of labor were unleashed (Shepherd \& Stone, 2013). In China's case, this was achieved under the tight control of semi-state corporations and the first police state dedicated to export-oriented industrialization. Footloose capital could rejoice as billions of mostly unskilled workers lined up for obedience school. For its part, India benefited from decades of centralized technocratic planning that had produced huge cohorts of educated people who also spoke English, the world's lingua franca. It garnered a great deal of skilled work in the services sector, from software to sales. At the same time, the spread of the internet permitted unprecedented surveillance of inventory and labor. "Cool stuff" abounded, made by pliant employees. This development immediately cut into the lives of unskilled First World labor (Fuchs, 2014).

The new wave of workers was not just doing traditional manufacturing, but rather, cultural manufacturing: assembling vast numbers of machines dedicated to making meaning, such as photocopiers, printers, laptops, tablets, and phones. They became the invisible background of cultural work. Along with developments in the digital exchange of meaning, this had profound implications for a domain that the Global North had long regarded as its own: the information society. 


\section{Information Society}

For decades prior to the NICL taking effect, developments in the media and associated technologies of knowledge had been likened to a new Industrial Revolution or the Civil and Cold Wars, touted as a route to economic development as well as cultural and political expression. In the 1950s and '60s, futurists identified "knowledge workers" as vital to information-based industries that would generate productivity gains and competitive markets and expand the middle class (Bar \& Simard, 2006). US Cold Warriors like National Security Advisor Zbigniew Brzezinski, cultural conservative Daniel Bell, and professional anti-Marxist Ithiel de Sola Pool saw converged communications and information technologies removing grubby manufacturing from North to South and ramifying US textual and technical power, provided that the blandishments of socialism, and negativity toward global business, did not create class struggle (Bell, 1977).

The NIDL would supposedly not impoverish the West, because the latter would embark on structural adjustment by retraining blue-collar workers away from assembly and towards services. The neoclassical economist Fritz Machlup produced a bedside essential for true believers in doctrines of human capital (Machlup, 1962). The party line was that the middle class would continue its merry investment in human capital through higher education. There would be four, largely painless, changes from production to services: the preeminence of professionalism and technique, the importance of theory to innovate and generate public policies, the formation of a discourse of the future, and new intellectual technologies to help make decisions (Mattelart, 2003). This technocratic vision, dominated by experts, promised a world of modernity, of rationality, of the ability to apply reason to problems and seek salvation in the secular. It was amenable to the center-left as well as the right, fulfilling Keynes' idea of a fifteen-hour work week enabled through technology and compound interest just as it suited Machlup's model of investment in the self (Keynes, 1963). The fantasy has suited policy makers and think tanks ever since, for reasons of ideology as much as efficiency.

Ronald Reagan launched his successful 1966 campaign for the governorship of California in this context, saying: “I propose . . . 'A Creative Society' . . . to 
discover, enlist and mobilize the incredibly rich human resources of California [through] innumerable people of creative talent." (Reagan, 1966). That rhetoric publicly birthed today's idea of technology unlocking the creativity that is allegedly lurking, unbidden, in individuals, thereby permitting them to become happy, productive-and without full-time employment.

Reagan opposed then-President Lyndon Johnson's rhetoric of a "Great Society," a term coined half a century earlier by the Fabian Graham Wallas (1967). His acolyte Walter Lippmann spoke of 'a deep and intricate interdependence' that came with 'living in a Great Society' and worked against militarism and other dehumanizing tendencies that emerged from 'the incessant and indecisive struggle for domination and survival.' (1943). Lippmann influenced Johnson's invocation of the "Great Society" (minus its anti-militarism) which became a foundational argument for competent, comprehensive social justice through welfarism and other forms of state intervention.

Most of that "Great Society" vision has been undermined by decades of neoliberalism, operating under the sign of the information society. Today's bourgeois economists argue against state participation in development because private initiative and new technology obviate the need for it. For example, they claim that cell phones have streamlined markets in the Global South by making market data easily available, thereby enriching people in zones where banking and economic information are scarce. Mobile telephony supposedly guarantees 'the complete elimination of waste' and massive reductions in poverty and corruption by empowering individuals (Jensen, 2007).

This richly utopian discourse has seen a comprehensive turn away from researching and combating unequal infrastructural and cultural exchange, towards an extended dalliance with new technology and its supposedly innate capacity to endow users with transcendence (Ogan et al; 2009). New media technologies are said to obliterate geography, pollution, sovereignty, and hierarchy in an alchemy of truth and beauty. Corporate and governmental cultural gatekeepers and hegemons are allegedly undermined by today's innovative possibilities of creation and distribution. The comparatively cheap and easy access to making and circulating meaning 
afforded by internet media and genres is thought to have eroded the one-way hold on culture that saw a small segment of the world as producers and the larger segment as consumers. New technologies supposedly allow us all to become simultaneously cultural consumers and producers (prosumers) and environmental guardians while the world economy glides into an ever-greener post-industrialism - no more factory conditions, no more factory emissions (Ritzer \& Jurgenson, 2010).

\section{Cognitariat}

How can we theorize such developments? The philosopher Antonio Negri redeployed the concept of the cognitariat from the late lapsed leftist and Reaganite futurist Alvin Toffler to account for the change (Negri, 2007; Toffler, 1983). Negri defines the cognitariat as people undertaking casualized cultural work who have heady educational backgrounds yet live at the uncertain interstices of capital, qualifications, and government in a post-Fordist era of mass unemployment, limited-term work, and occupational insecurity. They are sometimes complicit with these circumstances, because their identities are shrouded in autotelic modes of being: work is pleasure and vice versa, so labor becomes its own reward (Gorz, 2004).

In the new era, readers become writers, listeners transform into speakers, viewers emerge as stars, fans are academics, and vice versa. Think of the job prospects that follow! Zine writers are screenwriters. Bloggers are copywriters. Children are columnists. Bus riders are journalists. Coca-Cola hires African Americans to drive through the inner city selling soda and playing hip-hop. AT\&T pays San Francisco buskers to mention the company in their songs. Urban performance poets rhyme about Nissan cars for cash, simultaneously hawking, entertaining, and researching. Subway's sandwich commercials are marketed as made by teenagers. Cultural-studies majors become designers. Graduate students in New York and Los Angeles read scripts for producers then pronounce on whether they tap into the Zeitgeist. Unpaid interns to public-relations firms post putatively organic desires for products and services on social media as part of lucrative contracts for their elders and betters.

New "jobs" are emerging in surveillance. Audience members spy on fellow-spectators in theaters to see how they respond to coming attractions. Opportunities to 
vote in the Eurovision Song Contest or a reality program disclose the profiles and practices of viewers, who can be monitored and wooed in the future. Twitter and Facebook sell information about users' past and present lives and likes, monitoring their every move. End-user licensing agreements ensure that players of corporate games on-line sign over their cultural moves and perspectives to the companies they are paying in order to participate (Maxwell \& Miller, 2012; Miller, 2007; FTC, 2011). The labor of consumers becomes the property of companies they are patronizing; a neat corporate trick.

The amount of information about people on line, the speed with which it is collected and analyzed, and the way it is articulated by marketers to corporations have dramatically increased in both reach and effect as part of the information society. The US Federal Trade Commission has alerted citizens to how much surveillance they are subject to in the name of consumer sovereignty. It claims that if consumers give companies information about themselves, their desires will be met more easily and rapidly. The Commission acknowledges concerns about the use of such data by firms (FTC, 2012), but fails to point out that beyond privacy lie the ownership and use of ordinary people's intellectual property: their ideas and identities should be theirs to share or not, for monetary gain or not. So it's not just that they must be allowed to keep things private-they should be paid by corporations that wish to collect, analyze, exploit, and sell information about them. Dividing lines between labor and play are being redrawn, simultaneously before our eyes and behind our backs. Facebook and academia work in step, rejoicing in proving the uncanny accuracy of prosumer control through the use of big data (Kosinski, Stillwell, \& Graepel, 2013).

Target was rightly embarrassed by the revelation in 2012 that it analysed purchasing patterns by women to determine whether they were pregnant, then proceeded to advertise pregnancy and baby products through direct mailing to their homes. That risked disclosing their situation to people from whom they might wish to keep such matters private, be they parents, grandparents, children, lovers, or lodgers (Duhigg, 2012). Despite such outrages, the paucity of citizen knowledge of the extent and impact of corporate surveillance is striking (Madden et al., 2013). 
And there is another side to this best of all possible worlds: the information society has disempowered the very people around whom it was built-the educated middle class. This has been achieved by drawing on the example of fringe intellectuals, from jazz musicians to street artists. These cultural workers have long labored without regular compensation and security and are now models for the expectations we are all supposed to have today, as opposed to our parents' or grandparents' assumptions about life-long, or at least steady, employment. Cultural production shows that workers can move from security to insecurity, certainty to uncertainty, salary to wage, firm to project, and profession to precarity-with smiles on their faces (Ross, 2009). The information society distributes that systematic insecurity across industries. Contemporary business leeches luxuriate in flexibility over the people they employ, the technologies they use, the places where they do business, and the amounts they pay-and inflexibility of ownership and control (Mosco, 2014).

Consider the advertising agency/broker Philadelphia/Dana Point's Poptent. It undercuts conventional competitors in sales to major clients by exploiting prosumer artistic labor in the name of "empowerment." 2 That empowerment takes the following form: the firm pays the creator of a homemade commercial US\$7500; it receives a management fee of US $\$ 40,000$; and the buyer saves about US $\$ 300,000$ on the usual price (Dawn, 2012). Once Poptent established a cadre of cheap labor, it ceased being an open forum for new talent, relying instead on invitees. Previously gullible neophytes who had embraced the company and its kind are now adopting the critical pose that industry veterans have long favored (Dan, 2014).

The lessons could not be more apparent. Despite the technocentric projections of Cold War futurists and contemporary web dreamers, the wider culture industries largely remain controlled by media and communications conglomerates, which frequently seek to impose artist-like conditions on their workforces (the broadcast versus cable TV labor process in the US is a notorious instance-the former is unionized, the latter is not, with commensurate differences of income and benefits). They gobble up smaller companies that invent products and services, "recycling audio-visual cultural material created by the grassroots genius, exploiting their intellectual property and generating a standardized business sector that excludes, 
and even distorts, its very source of business," to quote The Hindu (Ramanathan, 2006). In other words, the cognitariat-interns, volunteers, contestants, and so on-creates "cool stuff" whose primary beneficiaries are corporations (Ross, 2006; Marcus, 2005).

Cultural labor incarnates this latter-day loss of life-long employment and relative income security among the Global North's industrial proletarian and professional-managerial classes. A rarefied if exploitative mode of work-that of the artist and artisan in the field of culture-has become a shadow-setter for conditions of labor throughout the information society.

\section{The New International Division of Cultural Labor and Hollywood}

This new division of labor is becoming as global as the manufacturing one that preceded it. Alongside a casualization of middle-class jobs within the Global North, there is also a replication of the NIDL: a New International Division of Cultural Labor. By the 1980s, as culture became increasingly commodified and governmentalized and drew closer to the center of the world economy, it fell subject to the same pressures as secondary industries. Hence the success of Mindworks Global Media, a company outside New Delhi that provides Indian-based journalists and copyeditors to newspapers whose reporters are supposedly in the US and Europe. It promises 35-40 percent cost savings by contrast with workers at the outlets in question (Lakshman, 2008).

Hollywood is a classic instance of this transformation from industrial to post-industrial work. A car-assembly-like studio system of production (Fordism) characterized the industry between about 1920 and 1970. But while films were made en masse, the routinization, deskilling, and invigilation that manufacturing machinery and scientific management forced on factory workers did not occur. Many studio employees participated in the labor process at various points rather than being restricted to one, and their work was not easily undertaken by others. In addition, they had strong social interaction across class barriers through face-toface connection (Powdermaker, 1950). Ironically, these differences from classic 
working-class anomie helped open the way to intense networking as a substitute for factory discipline.

Hollywood Fordism eroded from the late 1940s as a consequence of vertical disintegration, suburbanization, and televisualization. These three transformations occurred thanks to a mixture of state action and demographic change: trust-busting by the Department of Justice, returning white GIs clutching preferential housing deals, and the spread of TV combined to turn urban moviegoers into suburban homebodies. The conjuncture gradually transmogrified Hollywood workers from studio staff, with regular, longstanding relations of subordination and opportunity, into transient, irregular employees working for small, short-lived firms.

The US film industry thus became a pioneer of the type of employment beloved of contemporary management (post-Fordism). With jobs constantly starting, ending, and moving, it exemplified "flexible specialization"-a shift from lifelong employment to casualized labor (Piore \& Sabel, 1984). The pharmaceutical sector, for instance, has looked to this model for its own pernicious development (Surowiecki, 2004).

Hollywood workers and bosses strike complex, transitory arrangements on a project basis via temporary organizations. Small or large numbers of diverse hands are involved at different stages, sometimes functioning together and sometimes semi-autonomously:

independent contractors coalesce for a relatively short period of time around one-off projects to contribute the organizational, creative, and technical talents that go into the production of a film. The inherent transience of this production system results in a high rate of tie formation and dissolution (Ferriani, Cattani \& Baden-Fuller, 2009).

It's a bit like the hothouse of a conference, protest, or convention. Places, time, and groups have effects on everything from textual cues, policy incentives, and educational support to funding, skills, costs, and marketing. Work can be subject to local, national, regional, and international fetishization of each component, 
matching the way that the labor undertaken is largely fetishized away from the final text, rendered invisible other than to dedicated watchers of closing credits sequences. Conventional organizational charts are inadequate representations of such arrangements, which lack the conventions of institutionalized hierarchy but are marked by the eternal presence of managerial surveillance.

Hollywood labor inhabits a global network of subcontracted firms and individuals, mediated through unions, employer associations, education, and the state. Overseas governments are centrally involved. German financing of Hollywood films in the early 21st century was frequently stimulated by tax breaks for lawyers, doctors, and dentists. French money came from firms with state subvention in other areas of investment, such as cable or plumbing, that then subsidized US studios. TV shows shot in Canada relied on welfare to attract US productions. And domestically, state, regional, and municipal commissions across the US competed via reduced local taxes, free policing, and the closure of putatively public way-fares (Miller et al. 2005).

The gullible states that engage in this largesse do so for a variety of reasonscreating jobs during film or TV shoots, engendering public awareness of their localities to boost tourism, cleaving glamor to sponsoring politicians, fulfilling the remit of culturecrats, and satisfying the needs of powerful businesspeople. There is no evidence that the subsidies pay for themselves in terms of private-sector expenditure during production or the establishment of an ongoing filmmaking infrastructure. Such prospects are jeopardized by the big two locations, Los Angeles and New York, and bidding contests between states that ratchet up the terms they offer California-based producers (Tannenwald, 2010; Foster, Manning \& Terkla, 2013).

This public funding of Hollywood, supposedly the acme of laissez-faire business success, is one of those spheres of life where neoclassical economics and radical political economy can agree on both a target and a way of attaining it: uncovering and problematizing state subsidies that enable affluent, indolent bourgeoisies to thrive and consign established, skilled workers to precarious circumstances (Tannenwald, 2010; Miller, 2005). For decades, Los Angeles producers have shot in the 
UK, Australia, Canada, the former Soviet sector, and other locales to take advantage of government incentives, advanced technology, and compliant labor (Miller et al., 2005).

The impact on production in LA has been profound, even if above-the-line labor still mostly lives and pays taxes there:

In 1997, the majority of large-budget studio features were produced in California, with many in L.A. By 2013, most high-value feature projects were made elsewhere; just two of the year's live-action movies with budgets above $\$ 100$ million were filmed in L.A. Today, most local Feature production is for small, independent projects that offer reduced employment and spending benefits (FilmL.A., 2014).

Entertainment media jobs in the Los Angeles metropolitan region declined by 7.7 percent between 2005 and 2010, manifesting the impact of the financial crisis. However, for Los Angeles, which has consistently maintained at least a 45 percent share of the US national film and television employment and is the single most important center of film and television production in the USA (with a 10.71 location quotient for the industry code defining the motion pictureand video-recording industry), the crisis punctuated a longer-term decline in employment and production capacity ... on-location shooting of feature films reached a high of 13,980 days in 1996; by 2009, it was only 4976 days ... location activity for television productions reached a high of 25,277 days in 2008, reflecting the expansion of low-cost reality and dramatic productions for cable television. Demonstrating the impact of the recession, on-location television production days in Los Angeles dropped by almost 17 percent in 2009. So, the more-lucrative film production jobs were replaced during the decade by less-lucrative television jobs. These jobs then decreased as the recession took hold.... [T] he number of workers employed in films, television programs and commercials in 2010 in Los Angeles County was lower than that in any year since 2001. In addition, because of the supply chains that are connected to project-based production, California state employment numbers actually undercount employment losses in the entertainment industry agglomeration in Los Angeles: they 
do not include unemployment of part-time workers (nearly a quarter of the industry workforce) nor unemployment in ancillary business services such as property, houses and equipment rental shops, which depend on Los Angeles productions for their employment and profits (Christopherson, 2013:142).

The NICL has real, material effects as per the cognitariat/precariat more generally.

\section{Before and After Hollywood}

Theorizing the NICL has explained Hollywood's offshore actions, it has not clarified the totality of cultural labor. Because the concept concentrates on overtly cultural production, such as filming and editing movies, it has rather neglected both the shared and the different aspects of proletarian as opposed to middle-class experiences making culture: people living below the line in Hollywood versus above it (i.e. blue-collar rather than white-collar workers-electricians, not editors) and those manufacturing televisions versus writing programs to be seen on them. Recent developments in thinking through the supply chain of culture suggest that the analytic separation drawn between these two divisions of labor may no longer be legitimate, if it ever was. The latter frequently relies on the former and vice versa. It makes little sense, for example, to examine how films are made without looking at how film technology is made, while questions of design and software have mutual impacts on hardware. Tracking the life of the commodity sign necessitates a full-service approach to its existence, from mineral extraction to media screening.

One of the many shibboleths associated with the information economy is that it is dematerialized and hence environmentally and occupationally safe. This is conceptually and empirically false, which is particularly important when it comes to the material life of the technology that makes Hollywood happen (Maxwell \& Miller, 2005; Sandoval, 2014). Think of the health-and-safety risks endured by camera operators, stunt-people, models, singers, transport captains, set carpenters, cell-phone testers, caterers, and computer habitués. And the NICL should address the part played by the informal economic sector and indentured labor in manufacturing, circulating, using, disposing of, and recycling electronic gadgetry. 
That grey economy features everything from gigantic malls across the cities of the Global South, with shops that sell producing services, self-help salsa books and videos, and pirated or stolen hardware and texts, to huge mountains of discarded electronic gadgetry that ragpickers disassemble in search of parts or minerals for re-sale.

In keeping with the information society's manifold fantasies, the International Telecommunication Union (ITU) gleefully predicts that communications technologies will connect the 6.5 billion residents of the Earth in 2015, enabling everyone to "access information, create information, use information and share information." This development will magically "take the world out of financial crisis," principally thanks to developing markets (Hibberd, 2009). But the ITU is wise enough to say that these technologies cause grave environmental problems, so it presses for "climate neutrality" and greater efficiency in energy use (ITU, 2008; ITU, 2009). The 2008 World Telecommunication Standardization Assembly in South Africa encouraged members to reduce the carbon footprint of communications, in accord with the United Nations Framework Convention on Climate Change (Touré, 2008).

In similar vein, the Organization for Economic Co-operation and Development says communications can play a pivotal role in developing service-based, low-polluting economies in the Global South through energy efficiency, adaptation to climate change, mitigation of diminished biodiversity, and diminished pollution, but cautions that such technological advances may produce negative outcomes. For example, remote sensing of marine life could encourage unsustainable fishing (Houghton, 2009).

Then there is that delightful metaphor we are all now using: "the cloud." It signifies the place where all good software goes for rest and recuperation, emerging on demand, refreshed and ready to spring into action. Seemingly ephemeral and natural-clouds are benign necessities of life that rain on fields then go awaynothing could be further from the truth when it comes to the power-famished, coal-fired server farms and data centers rendered innocent by this perverse figure of speech (Mosco, 2014). 
No-one would wish to pour on this parade, but let's think about the fact that the US National Mining Association and the American Coalition for Clean Coal Electricity gleefully avow that the "Cloud Begins with Coal." They boast that the world's information and communications technologies use 1500 terawatt hours each year-equivalent to Japan and Germany's overall energy use combined and 50 more than the aviation industry. That amounts to 10 of global electricity (Mills, 2013). The Association and the Coalition even quote poor old Greenpeace (Greenpace, 2012) on the horrendous environmental implications of data centers, as evidence of "healthy" growth for extractive industries. Big mining and big coal just can't help themselves, so excited are they by the centrality of their polluting ways for the present and future of the cloud. Meanwhile, Google disclosed in 2011 that its annual carbon footprint was almost equal to that of Laos or the United Nations Organization, largely due to running its search engines through clouds (Clark, 2011).

And when obsolete cell phones or other communication technologies are junked, they become electronic waste (e-waste) the fastest-growing component of municipal cleanups around the Global North. E-waste poses serious threats to worker health and safety wherever plastics and wires are burnt, monitors smashed and dismantled, and circuit boards grilled or leached with acid, while the toxic chemicals and heavy metals that flow from such practices have perilous implications for local and downstream residents. This accumulation of electronic hardware causes grave environmental and health harm as noxious chemicals, gases, and metals from wealthy nations seep into landfills and water sources across Malaysia, Brazil, South Korea, China, Mexico, Viet Nam, Nigeria, and India, inter alia. The e-waste ends up there after export and import by "recyclers" who eschew landfills and labor in the Global North in order to avoid the higher costs and regulatory oversight in countries that prohibit such risks to the environment and workers. Businesses that forbid dumping e-waste in local landfills as corporate policy readily mail it elsewhere to take advantage of the NICL.

In that "elsewhere," pre-teen girls pick away without protection at used televisions and computers, recycling and cleaning the detritus of the information socie$t^{3}$. The appalling morbidity rates of these ragpickers have stimulated a stream of 
studies that directly associate work in the informal e-waste economy with occupational health and safety risks. It's significant that much of this research comes from, as well as about, the Global South, with distinguished contributions from African, Asian, and Latin American scholars and activists (Devi, Arza, Swamy \& Krishna, 2014; Nnorom \& 0sibanjo, 2009; Reis de Oliveira, Moura Bernardes \& Engel Gerbase, 2012; Wong et al., 2007).

Back in the "rich" world, US prisoners work compulsorily for less than anybody else would, doing everything from assembling to recycling electronics. The US Constitution helpfully guarantees corporations this right as part of the quid pro quo for the abandonment of slavery. Imprisoned indentured labor is an attractive option for US foreign firms, because it avoids the transportation costs associated with offshore enterprises and satisfies the bizarre desire to displace the male working class of color from education into incarceration. Cultural companies that exploit these opportunities include AT\&T, IBM, Intel, Lucent Technologies, Victoria's Secret, Texas Instruments, Dell, and Compaq (LeBaron, 2008; Conrad, 2011). The significance for Hollywood is obvious given its reliance on such corporations.

\section{Conclusions}

Cultural trade around the world increased from US $\$ 559.5$ billion in 2010 to US $\$ 624$ billion in 2011 (UNCTAD, 2013). But inequality has accompanied this boom. For example, the cost of broadband in the Global South is 40.3 of average individual Gross National Income (GNI). Across the Global North, by comparison, the price is less than 5 of GNI per capita (ITU, 2012). Meanwhile, structural injustice and precarious employment center cultural work, adopting and adapting its proletarian aspects for use across economies in order to diminish the privileged status of workers in the Global North. Technological changes that both enabled the centrality of culture and democratized it are revealed to be ecologically destructive, just like their supposedly more material equivalents in construction and manufacturing.

So what should be done to ameliorate this situation? Clearly, casualized labor suits some people in particular places at certain moments in their lives; but to 
make it a requirement, a norm, means that there need to be accompanying programs to ameliorate the inequalities and poverty that this can cause through the consolidation of primary and secondary labor markets, which segregate societies by power and money. The answer lies in environmental justice and welfare tailored to patterns of employment (Murray \& Gollmitzer, 2011). This also necessitates global solidarity with workers at the sharpest end of the NICL-those who make and recycle electronic devices under oppressive, dangerous circumstances, and struggle for political rights (Chan, Pun \& Selden, 2013).

It's clear that the NICL has become a model for exploitation across territories, industries, and occupations, so thinking about it critically remains vital. Analytically, we need to focus on the division of labor as a theoretical, empirical, and organizational tool if we are to understand everyday work in a way that can enrich and liberate it in accord with ecological and employee experiences and necessities. Labor and environmental justice are intimately implicated with the increasingly worldwide power of culture-and the means of powering it. The theory of the NICL can contribute to those goals once it accounts for the entire life of the commodity sign, from conception to manufacture to distribution to use-and finally, recycling.

\section{Notes}

[1] Snow was troping Thomas Hobbes, who described a world of "continual fear and danger of violent death, and the life of man solitary, poor, nasty, brutish, and short," Of Man, Being the First Part of Leviathan, Chapter XIII

[2] There are many other examples, of course. Yannig Roth and Rosemary Kimani, Crowdsourcing in the Production of Video Advertising: The Emerging Roles of Crowdsourcing Platforms, CR-1318 http://prism.univ-paris1.fr/New/cahiers/2013/CR13-18.pdf.

[3] Readers may wish to consult Basel Action Network and Silicon Valley Toxics Coalition, Exporting Harm: The High-Tech Trashing of Asia (Seattle: Basel Action Network, 2002); Sherry Lee, "Ghosts in the MACHINES," South China Morning Post Magazine, May 12, 2002 http://ban.org/ library/ghosts_in.html; Xin Tong and Jici Wang, "Transnational Flows of E-Waste and Spatial Patterns of Recycling in China," Eurasian Geography and Economics 45. 8 (2004): 608-21; Zack Pelta-Heller, "HP's Printer Cartridges Are an E-Waste Disaster-Does the Company Really Care?," AlterNet, October 29, 2007 http://goo.gl/wSMN82; Coby S. C. Wong, S. C. Wu, Nurdan S. Duzgoren-Aydin, Adnan Aydin, and Ming H. Wong, "Trace Metal Contamination of Sediments in an E-Waste Processing Village in China," Environmental Pollution 145. 2 (2007): 434-42. 


\section{References}

Bar, F. \& Simard, C. (2006) "From Hierarchies to Network Firms." In The Handbook of New Media: Updated Students Edition, edited by Leah Lievrouw and Sonia Livingstone, 350-63. Thousand 0aks: Sage

Basel Action Network and Silicon Valley Toxics Coalition (2002). Exporting Harm: The High-Tech Trashing of Asia. Seattle: Basel Action Network.

Bell, D. (1977) "The Future World Disorder: The Structural Context of Crises." Foreign Policy 27, 109-35.

Brzezinski, Z. (1969) Between Two Ages: America's Role in the Technotronic Era. New York: Viking Press.

Cardoso, F.H. (2009). "New Paths: Globalization in Historical Perspective." Studies in Comparative International Development 44. 4, 296-317.

Chan, J., Pun, N. \& Selden, M. (2013) "The Politics of Global Production: Apple, Foxconn and China's New Working Class." New Technology, Work and Employment 28. 2, 100-15.

Chmielewski, D. C. (2012, May 8) "Poptent's Amateurs Sell Cheap Commercials to Big Brands." Los Angeles Times, http://goo.gl/nKg4Ve

Chmielewski, D.C. (2012, May 8) "Poptent's Amateurs Sell Cheap Commercials to Big Brands," Los Angeles Times http://goo.gl/eECrKT

Christopherson, S. (2013) "Hollywood in Decline? US Film and Television Producers Beyond the Era of Fiscal Crisis." Cambridge Journal of Regions, Economy and Society 6. 1, 141-57.

Clark, D. (2011, September 8) "Google Discloses Carbon Footprint for First Time." Guardian https://goo.gl/kYlPfp

Conrad, S. M. (2011) "A Restorative Environmental Justice for Prison E-Waste Recycling." Peace Review 23. 3, 348-55.

Dan, L. (2014, February 20) "Is This the End of Poptent as We Know It?" Video Contest News http://goo.gl/aaCHFz

Devi, K. S., Arza V., Swamy, V. S. \& Krishna, R.H. (2014) "Studies on the Solid Waste Collection by Rag Pickers at Greater Hyderabad Municipal Corporation, India." International Research Journal of Environment Sciences 3. 1, 13-22. Duhigg, C. (2012, February 19) “Psst, You in Aisle 5." New York Times: MM30. 
Federal Trade Commission (2012) Protecting Consumer Privacy in an Era of Rapid Change: Recommendations for Businesses and Policymakers http://goo.gl/ H32eya

Ferriani, S., Cattani, G. \& Baden-Fuller, C. (2009) "The Relational Antecedents of Project-Entrepreneurship: Network Centrality, Team Composition and Project Performance." Research Policy 38. 10, 545-558.

FilmL.A. (2015) Research. Filming On Location Los Angeles 1993-2013. Los Angeles: FilmL.A. Inc.

Foster, P., Manning, S. \& Terkla, D. (2013) "The Rise of Hollywood East: Regional Film Offices as Intermediaries in Film and Television Production Clusters." Regional Studies 10.1080/00343404.2013.799765.

Fröbel, F., Heinrichs, J. \& Kreye, 0. (1980) The New International Division of Labour: Structural Unemployment in Industrialised Countries and Industrialisation in Developing Countries. Translated by Pete Burgess. Cambridge: Cambridge University Press; Paris: Éditions de la Maison des Sciences de l'Homme.

FTC (2011, November 29) In the Matter of Facebook, Inc. FTC File No. 0923184 http://www.ftc.gov/enforcement/cases-proceedings/092-3184/facebook-inc.

Fuchs, C. (2014) Digital Labour and Karl Marx. New York: Routledge.

Gorz, A. (2004) "Économie de la connaissance, exploitation des savoirs: Entretien réalizé par Yann Moulier Boutang and Carlo Vercellone." Multitudes 15 http:// multitudes.samizdat.net/Economie-de-la-connaissance.

Greenpeace (2012). How Clean is Your Cloud? http://goo.gl/5xsLXE

Hibberd, M. (2009) "Public Private Partnership." Telecoms.com, September 15, 2009 http://www.telecoms.com/14505/public-private-partnership/.

Higgott, R. (1993) Political Development Theory: The Contemporary Debate. London: Routledge.

Higgott, R. \& Robison, R. (Eds.) (1985) Southeast Asia: Essays in the Political Economy of Structural Change. London: Routledge \& Kegan Paul.

Hobbes, T. (2001) Of Man, Being the First Part of Leviathan n. d. New York: Bartleby. com http://www.bartleby.com/34/5/13.html.

Houghton, J. (2009) "ICT and the Environment in Developing Countries: Opportunities and Developments." Paper prepared for the Organization for Economic Cooperation and Development. http://www.oecd.org/ict/4d/44005687.pdf. 
International Telecommunication Union (2008). ICTs for Environment: Guidelines for Developing Countries, with a Focus on Climate Change. ICT Applications and Cybersecurity Division Policies and Strategies Department. Geneva International Telecommunication Union (2012). Measuring the Information Society: Executive Summary. Geneva: International Telecommunication Union

Jensen, R. (2007) "The Digital Provide: Information Technology, Market Performance, and Welfare in the South Indian Fisheries Sector." Quarterly Journal of Economics 122. 3: 879-924.

Kander, A. (2005) "Baumol's Disease and Dematerialization of the Economy." Ecological Economics 55. 1: 119-30.

Keynes, J.M. (1963). Essays in Persuasion. New York: W. W. Norton.

Kosinski, M., Stillwell, D. \& Graepel, T. (2013) "Private Traits and Attributes are Predictable from Digital Records of Human Behavior." Proceedings of the National Academy of Sciences of the United States of America 2013 doi: 10.1073/ pnas.1218772110.

Lakshman, N. (2008, July 8) "Copyediting? Ship the Work Out to India." Business Week. http://goo.gl/02QSDX

LeBaron, G. (2008) "Captive Labor and the Free Market: Prisoners and Production in the USA." Capital \& Class 32, 59-81.

Lee, S. (2002, May 12) "Ghosts in the MACHINES." South China Morning Post Magazine. http://ban.org/library/ghosts_in.html.

Lippmann, W. (1943) The Good Society. New York: Grosset \& Dunlap.

Machlup, F. (1962) The Production and Distribution of Knowledge in the United States. Princeton: Princeton University Press.

Madden, M., Lenhart, A., Cortesi, S., Gasser, U., Duggan, M., Smith, A. \& Beaton, M. (2013) Teens, Social Media, and Privacy. Pew Research Center and Berkman Center for Internet \& Society at Harvard University http://goo.gl/qGJ5vm Marcus, C. (2005) Future of Creative Industries: Implications for Research Policy. Brussels: European Commission Foresight Working Documents Series.

Marx, K. (1906) Capital: A Critique of Political Economy. Translated by Samuel Moore and Edward Aveling, edited by Frederick Engels. New York: Modern Library. Mattelart, A. (2003) The Information Society: An Introduction. Translated by Susan G. Taponier and James A. Cohen. London: Sage Publications.

Maxwell, R. and Miller, T. (2012a) Greening the Media. New York: Oxford University Press. 
Maxwell, R. and Miller, T. (2012b) "Warm and Stuffy": The Ecological Impact of Electronic Games." In The Video Game Industry: Formation, Present State, and Future, edited by Peter Zackariasson and Timothy Wilson, 179-97. London: Routledge.

Miller, T. (1989) “Possible Missions? Desirable Outcomes?" Filmnews 19. 2: 2

Miller, T. (1990a) "Mission Impossible: How Do You Turn Indooroopilly into Africa?" In Queensland Images in Film and Television, edited by Jonathan Dawson and Bruce Molloy, 122-31. St. Lucia: University of Queensland Press.

Miller, T. (1990b) "Mission Impossible and the New International Division of Labour." Metro 82, 21-28.

Miller, T. (2005) “Hollywood, Cultural Policy Citadel." In Understanding Film: Marxist Perspectives, edited by Mike Wayne, 182-93. London: Pluto Press.

Miller, T. (2007) Cultural Citizenship: Cosmopolitanism, Consumerism, and Television in a Neoliberal Age. Philadelphia: Temple University Press.

Miller, T., Govil, N., McMurria, J., Maxwell, R. \& Wang, T. (2005) Global Hollywood 2. London: British Film Institute.

Miller, T., Lawrence, G., McKay, J. \& Rowe, D. (2001) Globalization and Sport: Playing the World. London: Sage.

Miller, T., Yúdice, G. (2002) Cultural Policy. London: Sage.

Mills, M. (2013) The Cloud Begins with Coal: Big Data, Big Networks, Big Infrastructure, and Big Power: An Overview of the Electricity Used by the Global Digital Ecosystem. National Mining Association/American Coalition for Clean Coal Electricity http://www.americaspower.org/sites/default/files/Cloud_ Begins_With_Coal_Exec_Sum.pdf.

Mosco, V. (2014) To the Cloud: Big Data in a Turbulent World. Boulder: Paradigm Publishers.

Murray, C. \& Gollmitzer, M. (2011) "Escaping the Precarity Trap: A Call for Creative Labour Policy." International Journal of Cultural Policy 18. 4, 419-38.

Negri, A. (2007) goodbye mister socialism. Paris: Seuil.

Nnorom, I.C. \& Osibanjo, 0. (2009) "Toxicity Characterization of Waste Mobile Phone Plastics." Journal of Hazardous Materials 161. 1, 183-88.

Ogan, C. L., Bashir, M., Camaj, L., Luo,Y., Gaddie, B., Pennington, E., Rana, R. \& Salih, M. (2009) "Development Communication: The State of Research in an Era of ICTs and Globalization." Gazette 71. 8, 655-70. 
Park, S.C. (1997) "The Transformation of the South Korean Economy and International Economic Development in East and Southeast Asia." International Planning Studies 2. 2, 241-55.

Pelta-Heller, Z. (2007, October 29 ) “HP's Printer Cartridges Are an E-Waste Disaster-Does the Company Really Care?" AlterNet. http://goo.gl/URpGGm

Piore, M.J. \& Sabel, C.F. (1984) The Second Industrial Divide: Possibilities for Prosperity. New York: BasicBooks.

Powdermaker, H. (1950) Hollywood: The Dream Factory: An Anthropologist Looks at the Movie-Makers. Boston: Little, Brown \& Company.

Prebisch, R. (1982) The Crisis of Capitalism and the Periphery: 1st Raúl Prebisch Lecture. Geneva: United Nations Conference on Trade and Development.

Ramanathan, S. (2006, October 29) "The Creativity Mantra." The Hindu. http:// goo.gl/akE9PF

Reagan, R. (1966, April 19) "The Creative Society." Speech at the University of Southern California, http://www.freerepublic.com/focus/news/742041.

Reis de Oliveira, C., Moura Bernardes, A. \& Engel Gerbase, A. (2012) “Collection and Recycling of Electronic Scrap: A Worldwide Overview and Comparison with the Brazilian Situation." Waste Management 32. 8, 1592-1610.

Ritzer, G. \& Jurgenson, N. (2010) "Production, Consumption, Prosumption: The Nature of Capitalism in the Age of the Digital 'Prosumer'." Journal of Consumer Culture 10. 1: 13-36.

Ross, A. (2006-07) "Nice Work if You Can Get it: The Mercurial Career of Creative Industries Policy." Work Organisation, Labour \& Globalisation 1. 1, 1-19

Ross, A. (2009) Nice Work if You Can Get It: Life and Labor in Precarious Times. New York: New York University Press.

Roth, Y. \& Kimani, R. (2013) Crowdsourcing in the Production of Video Advertising: The Emerging Roles of Crowdsourcing Platforms CR-13-18 https://goo.gl/ Q8naKk

Sandoval, M. (2014) From Corporate to Social Media: Critical Perspectives on Corporate Social Responsibility in Media and Communication Industries. London: Routledge.

Shepherd, B. \& Stone, S. (2013) “Global Production Networks and Employment: A Developing Country Perspective." OECD Trade Policy Papers 154 http://dx.doi. org/10.1787/5k46j0rjq9s8-en. 
Snow, C. P. (1987) The Two Cultures and a Second Look: An Expanded Version of the Two Cultures and the Scientific Revolution. Cambridge: Cambridge University Press.

Sola, I. (1983) Technologies of Freedom. Cambridge, Mass.: Harvard University Press. Surowiecki, J. (2004) "The Pipeline Problem." New Yorker, February 16-23, 72.

Tannenwald, R. (2010) State Film Subsidies: Not Much Bang for Too Many Bucks. Washington: Center on Budget and Policy Priorities.

Telecommunication Union (2009). ITU Symposium on ICTs and Climate Change Hosted by CTIC, Quito, Ecuador, 8-10 July 2009: ITU Background Report. Telecommunication Development Sector. Geneva: International Toffler, A. (1983) Previews and Premises. New York: William Morrow.

Tong, X. \& Wang, J. (2004) "Transnational Flows of E-Waste and Spatial Patterns of Recycling in China." Eurasian Geography and Economics 45. 8, 608-21.

Touré, H. I. (2008, November 12-13) ITU Secretary-General's Declaration on Cybersecurity and Climate Change, High-Level Segment of Council. Geneva: International Telecommunication Union. http://goo.gl/IdHdHx

United Nations Conference on Trade and Development. (2013, May 15) "Trade in Creative Products Reached New Peak in 2011, UNCTAD Figures Show." http:// goo.gl/mxBvSn

Wallas, G. (1967) The Great Society: A Psychological Analysis. Lincoln: University of Nebraska Press.

Wong, C. S. C., Wu, S. C., Duzgoren-Aydin, N.S., Aydin, A. \& Wong, M.H. (2007) "Trace Metal Contamination of Sediments in an E-Waste Processing Village in China." Environmental Pollution 145. 2, 434-42. 